\title{
Intercultural content of a foreign language textbooks: concept, texts, practices
}

\author{
Elena Genrikhovna Tareva - Alla Viktorovna Schepilova - \\ Boris Vladimirovich Tarev
}

\section{DOI: 10.18355/XL.2017.10.03.20}

\begin{abstract}
At present, the potential of the intercultural approach to teaching foreign languages is looked at from different perspectives. Its acknowledged interpretation assumes that the student is constantly submerged in the situation of comparison between two cultures: the native and a different one. While acquiring another culture, he revises the native one, extending the vision of himself and of the surrounding world. This didactic concept requires changes in the system of foreign language teaching. The most obvious transformation must take place in the structure and content of the foreign language textbook.

The article contains the analysis of how the authors of modern textbooks of the French language understand the intercultural approach and how they implement it. This task is accomplished by a comparative analysis of the guidelines, texts, and educational assignments. The article raises an issue of how to prepare students for the dialogue of cultures.
\end{abstract}

Key words: the intercultural approach; the dialogue of cultures; foreign language textbook, interculturally marked components of a textbook

\section{Introduction}

Modern innovation processes underlying the system of higher education modernization, necessitate revision of all the components of teaching university students process. Significant transformations are taking place in the sphere of language education, aimed at shaping a new generation of linguists. An integrating element for all levels of education of linguists (Bachelor and Master) is intercultural communication, which is the main sphere of the professional activity of linguists, thus, defining its profile. Consequently, the primary strategic objective of teaching linguists at the present stage of language education policy is the formation of the students' intercultural communicative competence - the ability to take part in intercultural communication with a representative of another linguocultural community.

To achieve these goals it is necessary to reorient the entire educational system, including the modernization of teaching aids, the main one being a textbook as a learning management tool and as one of the most effective ways to optimize the education of foreign language university students. The problem of reorientation of foreign language textbooks in order for them to focus on the development of intercultural communicative competence is very acute. We need a new concept of the textbook, which would determine the intercultural specifics of its system and structure, thus, forming the image of a foreign language educational process in the format of Situation Modeling of intercultural communication. It is important to consider both positive and negative experience of designing teaching materials, instruments, practices, which are based on an intercultural approach. 


\section{Literature Review}

Throughout its history, the process of education of linguists has undergone more than one change of the dominant methodological concept: from grammartranslation method to cognitive ones, further to communicative, and finally to cultureoriented methods. At present, the communicative method, that was loudly announced in the second half of the twentieth century and for a long time was dominant in foreign language classrooms, requires some modification in the conditions of challenges specific for modern society. Today culture is penetrating and integrating in linguistic education, thus, having prepared a crisis of the ideology of communicative approach that for a long time determined the configuration of methodological system.

Today, in the post-communicative era hopes are connected with cultureoriented paradigm of the educational process in a linguistic university. In place of the dialogue of languages has come the dialogue of cultures - the form and method of communication of two or more cultures, where each party recognizes the other as an equal, shows interest in the other, recognizes its differences, respects its uniqueness, and at the same time through cognition and comparison deepens self-identity. In education of linguists intercultural approach is particularly required. This is evidenced by many works of modern researchers (N.D. Galskova, G.V. Elizarova, E.G. Tareva, I.I. Khaleeva).

The analysis of researchers' concepts allows us to conclude that some authors while defining the intercultural approach emphasize the significance of cognition of another culture, worldview, peculiarities (stereotypes, values, behavior) of speakers. Thus, the works manifest a certain kind of "culture-centrism" - with the focus on another culture. At the same time native culture acts as a means of "immersion" in this culture, a tool of revealing the universal (general) and differential (specific). Moreover, foreign academics highlight the facts of "linguistic imperialism» (Phillipson, 2003) and "cultural imperialism» (Said, 1993).

A wider view on the nature and objectives of the intercultural approach to teaching linguists presupposes displacement from the pedestal of the idea of ethnocentrism and culture-centrism in favor of cultural and ethnic equality (relativism), which provides the basis for dialogical type of human consciousness. When learning a foreign language and acquiring specific features of another individual's behavior a language learner expands his worldview in two directions. Simultaneously with the acquisition of knowledge and abilities of a foreign language, he is becoming aware of the peculiarities of his native culture, which he has not perceived before. Foreign language and culture act as a mirror that reflects the unperceived features of the native language and culture. Thus, the learner's worldview is being expanded through learner's comprehension both of another, and of his own culture. This provides an opportunity of secondary socialization in the process of intercultural interaction. In this case, foreign language learning strategy presupposes equal status of the two cultures involved in intercultural communication as a goal and a means of learning. The acquisition of facts of another culture is carried out in the following direction: (1) acquaintance with the fact of another culture $\rightarrow(2)$ its transfer to the native culture and an understanding of its features $\rightarrow$ (3) re-evaluation of facts of the native culture $\rightarrow$ (4) comprehension based on these positions of the phenomenon of another culture $\rightarrow$ (5) re-evaluation of the fact of another culture (Tareva, 2014). The final goal of such a complex cognitive activity is to acquire the phenomenon of another culture that many times (at different levels of rethinking) is passed through the native culture of the learner.

As can be seen, intercultural approach to the education of linguists involves consideration in the educational process of compulsory interaction of contacting language and conceptual systems of communicating participants - representatives of the two language communities. Application of this approach leads to the formation of interculturally oriented speaker (Byram, Zarate, 1991). This is a person who may, at 
first, cross any "boundaries" and act as an intermediary between two or more cultural identities. Secondly, such a person is not identified with a human, which "floats" over cultures, which is typical, for example, for tourists. This person wants to transform the intercultural movement into intercultural relations. For such a person it is not enough to feel a little surprise in what is interesting, attractive or exotic in another culture. It tends to the similar internal comprehension of "another" culture, which is inherent for the interlocutor. At the same time there occurs a better understanding of his own culture and cultural identity.

The development of interculturally oriented personality requires reorientation of the entire foreign language teaching system, and, above all, the textbook as the main component of the system. In the foreign literature we can see the attempts to describe such a textbook (Sercu, 2000; Shin, Eslami, Chen, 2011, Gómez Rodríguez, 2015, Ahmed 2016). In the textbooks the authors present various components of culture, but they do not take into account the importance of accentuation of the students' native culture in the content of the textbook.

\section{Aim of the Study}

The aim of the study is to examine the theoretical basis (the concepts) of a foreign language textbook that is based on the postulates of the intercultural approach, as well as the study of a series of foreign (French) textbooks from the point of view of the compliance of their content characteristics with intercultural didactic parameters.

The research questions are: What are the didactic parameters of an interculturally oriented foreign language textbook? What are the advantages and disadvantages of existing textbooks that are based on the intercultural approach? What are the recommendations to the authors of teaching materials, which ensure the development of the students' intercultural communicative competence?

\section{Materials and Methods}

The material of the study is the French language textbooks where authors proclaim commitment to the intercultural approach, given by the French term 'interculturel'. The material for the analysis consists of modern textbooks of three French publishers: Clé International, Didier, Hachette: levels A1, A2, and B1. In the first stage we analyze methodological notes (guides pédagogiques) of ten educationaland-methodological complexes (EMC). Contextual analysis of the term "interculturel" reveals three types of interpretation: as learning objectives, as a principle, and as a teaching technique. The second step is the analysis of the textbooks in order to identify the tactics applied for implementation of the intercultural approach. The objects of the analysis are assignments, types of the texts, their content, and visual presentation of the textbooks.

Research methodology is based on the provisions of anthropocentric, culturally oriented scientific paradigms related to the philosophical theory of personality, culture, communication, intercultural dialogue, leading role of activities in the intercultural development, and to the dialectical unity of theory and practice.

Complementary research methods are as follows:

- Theoretical methods: analysis and study of specific scientific and methodological literature on research issues; analysis of educational materials, abstract and logical general theoretical methods, as well as analysis and synthesis, content analysis of the French language textbooks.

General logical methods, which imply study and generalization of pedagogical experience related to the considered problem, conceptualization of

XLinguae Journal, Volume 10 Issue 3, June 2017, ISSN 1337-8384 
educational practice.

\section{Data, Analysis, and Results}

In the textbooks of the Publishing House Didier, such as Tempo (1997), Studio + (2004), and Édito (2006), the evolution concerning cultural aspect as an element of the content is most evident. Namely, very progressive for its time in terms of implementation of the communicative approach, Tempo pays a modest attention to cultural component of education. The authors propose the concept of "active civilization" (civilisation active), that represents the cultural fact through illustration, usually a situational picture, activating a speech activity. The rubric Civilisation gives photographs and short texts, demonstrating achievement of the French culture. The assertion that the cultural aspects of the content are presented in such a way so that students could "exercise the use of reflexive abilities" seem to be an exaggeration. Apart from the assignment to name the country of the learner, the textbook does not contain any tasks, allowing the student to "build a parallel with his culture", as it is stated in the methodological note.

The authors of Studio+ and Édito, mainly focusing in the methodological notes on the explication of the activity and communicative approaches, define "interculturel" role as "significant", explaining that their choice is the realization of an intercultural approach "through the revelation of the socio-cultural dimension of the French language." The methodological note explains the difference between cultural, socio-cultural, and sociolinguistic contents. The imperative is given to the obligatory exchange of views among students concerning these contents with consideration of the students' native culture. However, demonstrating the unity of language and culture in foreign language teaching content, Didier techniques retain commitment to linguistic aspect, ensuring popularity among many language learners. Understanding of the concept "interculturel" shows nothing innovative: the contents of texts and illustrations represent French culture; intercultural component is implemented through sporadic comparative reference and traditional themes of immigration and Francophony.

The authors of the teaching materials issued by the Publishing House Clé International - Campus (2005), Tout va bien (2005), Ici (2007), Écho (2010), and Zénith (2012) - in their methodological notes almost literally quote "Common European Framework of Reference for Languages: Learning, Teaching, Assessment" describing the activity approach, but ignore the intercultural and multicultural approaches stated in that document. The approach to representation of cultural content applied in these textbooks is directly aimed at comprehensive adaptation of students to a French language environment. The aim is to arouse interest in the French language culture, to reveal socio-cultural aspects of France and Francophony for learners, to familiarize them with the cultural elements that make it easier to communicate with native speakers. Each of the blocks of these textbooks solves the problem of adaptation to the specific context and situations of communication: the situations in which learners may occur (Tout va bien), which they will experience (Écho). The learners are taught to "behave according to cultural patterns of conduct adopted in France" (Campus), preparing to "fully integrate into French-speaking country" (Écho). They get cultural knowledge by working with "interesting texts illustrating the image of France which is open to the world, which is modern, uncomplexed, integrated into Europe and the world, and naturally the French language-speaking (naturellement francophone)" (Campus).

The only method of Clé International, in which the intercultural approach is stated in the methodological note as equal to activity approach, is a technique of the textbook Ici. But this fact, as well as the recognition of equality between mastering the language and culture, is not based on the desire to promote a real dialogue of cultures. The technique is designed to teach the French language in the French- 
speaking environment, namely in France. In addition to the traditional components the EMC contains a folder «Discovery» (fichier Découvertes), intended for extracurricular activities in the Francophonic environment (milieu homoglotte). That is, despite the obvious innovation of the educational product, the concept of attitude to the culture of France as to the target culture (culture-cible) is retained in full, although the once popular term is not mentioned, probably because of it being old-fashioned. Almost every first page of each Unit in the textbook Ici contains the assignment to compare the observed (theme, illustrations, texts) with the students' native culture. However, questions that encourage comparison are quite superficial, naive, and cannot be regarded other than the desire to follow the "officially accepted" concepts. For example, such questions are: Are there many different surnames in your country?, Do you have similar gestures?, Do you have sales in the shops?, What French brands are sold in your country?, What does your country export and where?

In the textbooks of the Publishing House Clé International "civilizational" approach to French culture as an element of learning content can be seen through the selected themes, the choice of culturally marked texts, and assessment materials. Let us show this by the example of the textbook Echo, revised and republished in 2010, i.e. in the period of universal acceptance of ideas of multi- and polyculturalism. The textbook's Units are rather eloquent: adapting to the new reality (s'adapter à de nouvelles réalités), coping with daily tasks (se débrouiller au quotidien), getting acquainted with the environment (découvrir un environnement), intergrating into society (s'intégrer dans la société), integrating into professional environment (s'intégrer dans un milieu professionnel), and, finally, being a citizen (participer à la vie citoyenne). Starting from level A2, cultural texts in Écho are distinguished by a large volume and give details of French society: constitution, administrative and political system, the system of education, achievements of science, industry and culture, the electoral system, presidents, political parties, volunteers' associations, mass-media, and traditions. The texts provide orientation in matters of everyday life: what topics for conversation are appropriate or should be avoided, how to behave at the table and taste the wine, how to fill out the documents for insurance, pay for purchases, which issues should be addressed in the gendarmerie, in the police station, in court, and in lawyer's office. Mandatory in each Unit is the Simulation page, which is a series of interrelated dialogues, the characters of which try to adapt to a new society. Dialogues are intended for simulation. Assessment materials summarize the skills of students in form of a certain type of activity. They estimate the ability to write a $\mathrm{CV}$, to enroll in the university, to inquire about the job vacancies (in Burgundy), to find accommodation, to maintain social contacts as French people do. In a letter to a friend the language learner should ask about the climate, the cost of living, the possibility of finding affordable housing. It is also important to be able to write requests, complaints, and even an open letter to the press. The texts depict a positive image of the country, culturally attractive, caring about the citizens: 35 -hour working week, the influential trade unions, fixed minimum wage. In the photos we see nice, good-looking people: entrepreneurs, journalists, designers. The characters of Simulation dialogues (that is, those who are integrated) have University education from Cambridge, or at least from Cairo, get jobs in multinational corporations that produce such goods as perfume, or work as editors of the prestigious magazines. Even in the section which is devoted to breaching the law we find nothing more serious than a fictitious marriage.

French authors of textbooks promoting Echo, however, declare that their methodology is interculturally oriented, providing as arguments the availability of such texts as an excerpt from the book of an American author Ted Stanger "Sacrés 
Français!" or "evidences» (témoignages) about what foreign students find strange in France, namely eating habits, kissing when greeting and parting, and other nice peculiarities. We admit that this is a look at themselves from outside, but it does not support the fact of the authors' commitment to the intercultural approach in its modern sense.

In 2012, the Publishing House Clé International published a textbook Zénith, implementing a polycultural approach, in which the key objective is the formation of ideas about the cultural and linguistic diversity of the target community. This conclusion can be drawn both from the content of the texts and the textbook illustrations. Neither methodological note nor Preface which are so common and specific for Clé clarify for the reader the didactic position of the authors in respect of the cultural component of education. Only Civilization page contains "some cultural information".

From the first Unit "Meet Friends" we see that the characters that appear and talk about themselves belong to different nationalities, live and work abroad. For example, a Chinese works in New York; a Japanese and an American meet in Paris, where the Russian Pierre Ivanov opens his photo exhibition; a Bulgarian working in Brussels, travels to his wife to London for the weekends. In Unit "Family," the girl says that her father is an Englishman, and mother is Irish, that they lived in Hong Kong, and they have moved to Paris. A young American woman tells how she helps her aunt decorate the castle, which was bought not far from Bordeaux. For the first time the textbook of Clé contains the text about French expats: a young man who prefers to live in Malaysia. Unit "Cinema" gives pictures of not only French but also American, Indian, Japanese illustrative posters. In Unit "City" there is information about China Town in Paris, and so on and so forth. In the pictures from Zénith we can see landscapes, famous monuments from different corners of the world.

The authors and editors diligently create a picture of the united and prosperous world. People often move from one country to another for studies or work, they are well-arranged in life, speak languages, travel a lot. The photos of the genre "scenes from life" are usually staged. Young people allegedly of different professions look like models. Noteworthy is the regularity with which the textbooks show photographs with two people belonging to different races: two young men in good suits, sitting at a cafe, two young pretty girls make a purchase or discuss the menu. The authors have taken care that even the language on Grammar pages matches the general concept. Thus, the use of partitive article is practiced in the situation of "a buy on the market in Mali"; comparative degree of adjectives is introduced in the text of a boxing match: Abdel Lyon against former champion of Russia Leonid Vlavska (Abdel est plus beau que Leonid).

Civilisation pages are not aimed at comprehensive and overwhelming introduction of all aspects of the life of French society. Of these, the most famous are selected: gastronomy and leisure. Pages represent Francophony, for example, comparing public transport in France, Belgium and Switzerland, or giving topical information, not related to a particular country, for example, strange hotels in the world, contemporary African art, adventure tours, new sports. Of course, the books contain enough variety of information about French culture, both in terms of cultivé (achievements), and in the sense of culturel (everyday practices). This information is given through authentic texts such as discussion on forums, social advertising, interviews, television program, museums and concerts posters, menus, advertisements. It is given in statistical summaries, often accompanied by the question about similar phenomenon in the culture of the students. In the texts that are aimed at the development of speech skills, obvious preference is given to universal themes: people being on a diet, looking for a life partner, earning money, writing some nonsense on Facebook, having some allergy, going on vacation. Thus, we can assume that for Clé International appearance of Zénith is practically a revolution in the 
understanding of the intercultural approach, although the manner of presentation of multicultural content looks somehow deliberate and sometimes hypertrophied.

Unlike Clé, Publishing House Hachette in its Teachers' Books always provides users with detailed methodological information about proposed teaching practices. The first mentioning of the intercultural approach is seen in the EMC Forum 2000, where methodological note explains the principles of selection of texts and illustrations. According to the authors, in the "factual" sense, selected texts are intended to provide situational language learning as well as the formation of ideas about modern France; in "behavioral" aspects the texts are designed to encourage students to understand the "other". Understanding, according to the authors, does not necessarily mean acceptance. Communicating in the proposed situations, the student retains his identity. This is namely understanding that is the major aim which becomes achievable through "relativization" of the native culture, through overcoming clichés and prejudices. This thesis shows that, despite the explicit question about the role of the learner's culture in comprehension of another culture, the methods of Forum are not too far from the ethnocentric concepts of the Publishing House Clé, realizing only one of their variations, namely the cultural and sensitive approach. The latter is defined as implying "awareness of differences between cultures, overcoming negative stereotypes in the intercultural communication" (Zhukova et al, 2013: 361).

In this sense, modern educational products of Hachette have undergone a significant change. Let's consider the method that is called Alter Ego +, which appeared in 2012. At the beginning of the methodological notes in the description of the activity principles of education the authors proclaim its strong link with the intercultural approach and their equivalence: students interact in a variety of authentic situations, being based on what they feel from their own experience and culture; cultural competences are formed in parallel with speech and language ones. Then the intercultural approach is recognized as the fundamental element of education and multiculturalism. Its purpose is to discover the culture of the "other" through reflecting on the native culture. Alter Ego + determines the dual task of rubrics in perception of cultural information about the countries of the target language. Besides that these rubrics contain assignments predetermined for "sharing" the native culture and life experiences. This principle position of authors also explains the selection of the themes of Units which are universal and close to all cultures.

All this can also be illustrated by the unusual for French textbooks choice of passages from belle-letters as an initial text of the Units (document déclencheur). These texts are intended to provoke reflection about life experience and native culture (Me and information, Me and consumption). Intercultural and personal are given a special focus in the process of education. Students not only get acquainted with another culture, they pose questions about it - Who is he? What does he want? How does he see it? - and return to themselves - How do I see it? Modern authentic texts, selected in accordance with a certain universal theme as well as attached corresponding assignments of comparative type allow to provide constant link and shift (va et viens) between inherent and foreign. This prepares students for real communication, real dialogue of cultures. For example, a wedding photo, plan of a house, a restaurant's menu, pictures of gifts for holidays, a questionnaire, a personal blog, ads, social or leisure advertising - almost everything makes it possible to understand another culture as well as the native one. We see obvious escape from primitive "comparative" questions, like: "Do you have it?" The regular for each lesson Exchange (Échange) exercise stimulates reflection both in terms of personal or native and nationally different. Which TV channels are preferable in your country? And which channels do you like? Do you have a popular e-bay site, give pros and cons. Is 
it good to learn two foreign languages at school? In the course of project development students prepare information about their city, about the holidays in their own country, they design the presentation about country, as if the coming year in France is declared the year of the students' country, offer the film to the Cannes Film Festival, develop a cultural program for their country, give talks about famous artists, on environmental problems of the country.

In the textbooks for Levels B1 and B2 we can see a noticeable expansion of the intercultural concept to the level of multicultural one, particularly by means of assignments that motivate learners to recognize other, different from Francophonic cultures. For example, imagine yourself as a representative of another nationality; chose appearance, name, occupation; compare your ideas about it with the fellow student who has chosen the same nationality. The textual material in the textbooks contains a large amount of "evidences" of real people (stating age, place of residence), not only the French but also the Bulgarians, Turks, British, Japanese. The rubric Rendez-vous alterculturel offers in the spirit of openness and pluralism the opinions of representatives of different nationalities concerning the topic of the Unit. So, we can find a story of a French woman about the attitude of Swedish students toward the money, the assessment by a Japanese woman of the French University, the comparison by an Englishman of French and British press, the story of a German woman about the environmental situation in Germany. The authors give the opportunity to listen to these recorded texts, that allows "to teach students to understand non-French speaking people who speak French." The authors try to provide "presence" of other cultures, even in Units devoted to France. For example, on the page of French theatre, we find critics of Dostoevsky's play. The Unit's assessment assignments suggest situations of universal nature, not being linked to French realities. For example, to play a scene where a chief chastises a subordinate for inappropriate look; in another episode to explain how to place online classified ad. It should be noted that the visuals in the textbooks have become more realistic. There we can see pictures of real people and events: the students protest against reforms, the favelas in Brazil, demonstrations demanding the release of hostages, solidarity with the victims of the tsunami in Japan. Photos and rare staged photographs encourage to reflection on personal and universal through the metaphorical image.

\section{Conclusion}

Having analysed French textbooks we can state that the importance of the intercultural approach is progressively increasing: from single teaching techniques to «interculturel» as an educational principle, and further, to the level of a fundamental element of education, that ensures the achievement of objectives - education of an individual in the spirit of multiculturalism. This analysis proves that acquisition of another culture through the native one is most adequately realized in Alter Ego + textbooks. Such possibility is based on the authors' intention to provide motivation for speech activity through dealing with universal, common human problems. The texts and visual aids are an opportunity " to meet another culture", to think and speak about what is different and what is inherent. The permanent addressing to the native culture, with consideration of "another" one leads to reassessment, new perception of the native reality (Tareva 2014). Also obvious is the trend in the binary nature of "cultural clashes" (Ter-Minasova 2008), the shift towards multiplicity of representations of cultures, the possibility of expressing different cultural meanings and values by means of the target language.

The successful realization of a particular educational strategy that is required at a certain period of time significantly depends on the quality of a foreign language textbook. The authors of educational materials take a very serious responsibility when they decide to design a textbook. They must keep pace with time, to follow new scientific trends, on the one hand, and the requirements of the society, 
on the other hand. Declaring that they are adherents of a particular approach, the authors should strictly follow its main provisions, steadily and systematically implement them in the structure and content of the textbook. There should be no substitution of concepts, the overwhelming ideology of the textbook design must be clearly observed.

The analysis of the actual material (the French language textbooks from various publishers) shows that, unfortunately, in most cases, these rules are breached, that there are some contradictions (proclaiming one approach, the authors realize the other / others). Often instead of initiating one generally stated idea the authors follow the path of eclectic mix of different strategies of foreign language teaching; and this combination is given as something new in the design of a textbook.

The selection, organization of the content of the textbook (teaching material), the sequence of educational activities must comply with the principles of intercultural approach to education. In the process of a textbook design these principles dictate the need to take into account the peculiarities of interaction of subjects (different cultures), expressed by means of a language. Such textbooks provide the focus on the accumulation of knowledge about the target language country's culture and the development of strategies that give the opportunity to understand the native and foreign cultures on the basis of their comparison. This will form a linguistic system of cognitive, emotional, evaluative, and behavioral attitudes to other cultures, i.e. to the universe, whose image is not only national but also global and multicultural.

\section{Bibliographic references}

AHMED SAMI HUSSEIN, A. 2016. An analysis of textbooks series based on English as International Language. International Journal of Research Studies in Language Learning, n. 5(1), pp. 99-103. DOI: 10.5861/ijrsll.2015.1234

BYRAM, M. - ZARATE, G. 1991. Investigating Cultural Studies in Foreign Language Teaching. Clevedon, Philadelphia: Multilingual Matters. ISBN 1853590878.

GOMEZ RODRIGUEZ, L. F. 2015. The cultural content in EFL textbooks and what teachers need to do about it. PROFILE Issues in Teachers' Professional Development, n. 17(2), pp. 167-187. DOI: http://dx.doi.org/10.15446/ profile.v17n2.44272.

PHILLIPSON, R. 1992. Linguistic Imperialism. Oxford: Oxford University Press

SAID, E.W. 1993. Culture and Imperialism. London: Vintage Books. ISBN 0-67975054-1.

SERCU, L. 2000. Acquiring intercultural communicative competence from textbooks. The case of Flemish adolescent pupils learning German. Leuven: Leuven University Press. ISBN 9789058670267.

SHIN, J. - ESLAMI, Z.R. - CHEN, W-CH. 2011. Presentation of local and international culture in current international English-language teaching textbooks. Language, Culture and Curriculum, vol. 24, pp. 253-268. DOI: 10.1080/07908318.2011.614694

TAREVA, E.G. 2011. Intercultural Approach to Education of Contemporary Linguists. The Problems of Theory, Practice, and Didactics of Translation. Language. Culture. Communication. Nizhny Novgorod, pp. 237-244. ISBN 978-5-85839-219-4.

TAREVA, E.G. - ANNENKOVA, A.V. - DIKOVA, E.S. - KAZANTSEVA, A.A. KAZANTSEVA, E.M. - KOLMAKOVA, O.A. - MAMETOVA, YU. F. PROSKURINA, G.A. 2014 Intercultural Foreign Language Education. Strategies and Tactics of Teaching Foreign Languages. Moscow: Logos. ISBN 978-5-98704-794-1. 
TER-MINASOVA, S.G. 2008. War and Peace of Languages and Cultures: Issues of Theory and Practice. Moscow: Slovo. ISBN 978-5-387-00076-8.

ZHUKOVA, I.N. - LEBEDKO, M.G. - PROSHINA Z.G. - YUZEFOVICH, N.G. 2013. The Dictionary of Terminology of Intercultural Communication. Moscow: FLINTA: Science. ISBN 978-5-9765-1083-8.

Words: 5292

Characters: 35498 (19,72 standard pages)

Prof. Elena Genrikhovna Tareva, PhD.

French Language Department

Moscow City University

$2^{\text {nd }}$ Selskokhoziastvenny Proezd 4

129226 Moscow

Russia

TarevaEG@mgpu.ru

Prof. Alla Viktorovna Schepilova, PhD.

French Language Department

Moscow City University

$2^{\text {nd }}$ Selskokhoziastvenny Proezd 4

129226 Moscow

Russia

SchepilovaAV@mgpu.ru

Associate Prof. Boris Vladimirovich Tarev, PhD.

Foreign Languages Department

National Research University Higher School of Economics

20 Myasnitskaya Street

110100 Moscow

Russia

btarev@hse.ru 